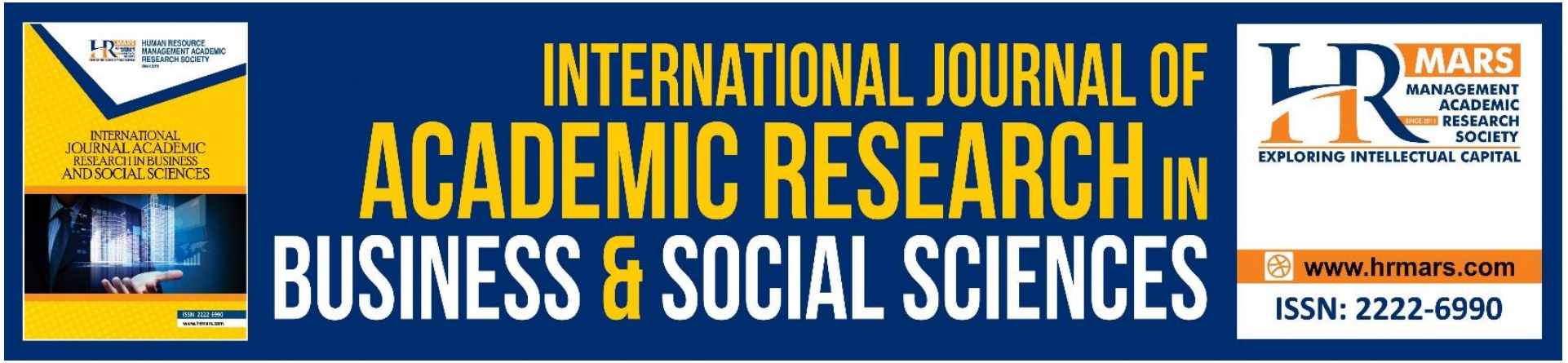

\title{
Challenges and Success Factors of Single Mother Cooperative in Peninsular Malaysia
}

\section{Azliana Mohd Jelani, Salmy Edawati Yaacob, Muhammad Hakimi Mohd Shafiai}

To Link this Article: http://dx.doi.org/10.6007/IJARBSS/v11-i7/10533

DOI:10.6007/IJARBSS/v11-i7/10533

Received: 27 May 2021, Revised: 30 June 2021, Accepted: 12 July 2021

Published Online: 29 July 2021

In-Text Citation: (Jelani et al., 2021)

To Cite this Article: Jelani, A. M., Yaacob, S. E., \& Shafiai, M. H. M. (2021). Challenges and Success Factors of Single Mother Cooperative in Peninsular Malaysia. International Journal of Academic Research in Business and Social Sciences, 11(7), 772-788.

Copyright: (c) 2021 The Author(s)

Published by Human Resource Management Academic Research Society (www.hrmars.com)

This article is published under the Creative Commons Attribution (CC BY 4.0) license. Anyone may reproduce, distribute, translate and create derivative works of this article (for both commercial and non-commercial purposes), subject to full attribution to the original publication and authors. The full terms of this license may be seen at: http://creativecommons.org/licences/by/4.0/legalcode

Vol. 11, No. 7, 2021, Pg. 772 - 788

Full Terms \& Conditions of access and use can be found at http://hrmars.com/index.php/pages/detail/publication-ethics 


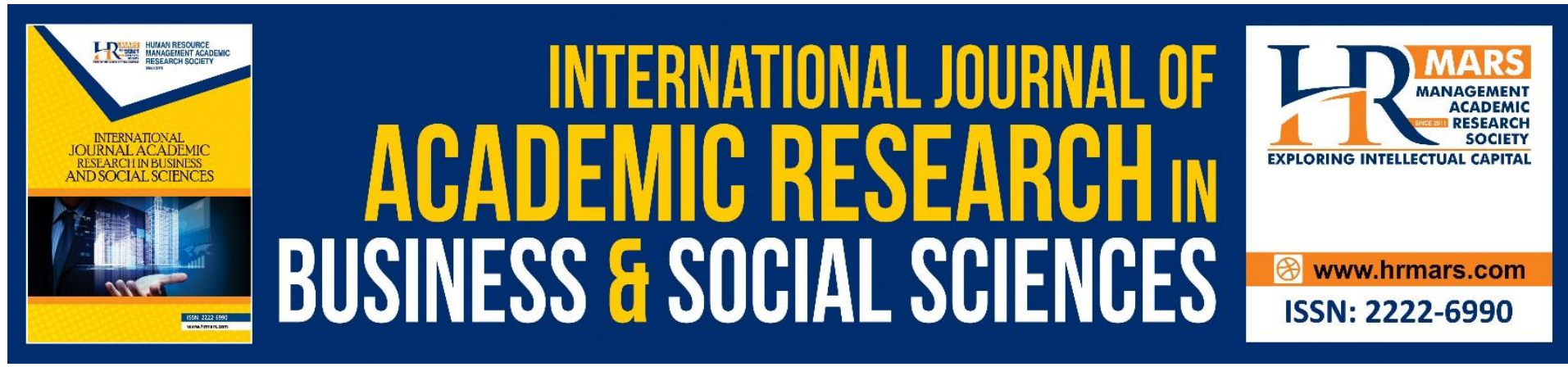

\title{
Challenges and Success Factors of Single Mother Cooperative in Peninsular Malaysia
}

\author{
Azliana Mohd Jelani \\ Institut Islam Hadhari, Universiti Kebangsaan Malaysia, 43600 Bangi, Selangor, Malaysia \\ Email: azliana.phd.ukm@gmail.com
}

Salmy Edawati Yaacob

Faculty of Islamic Studies, Universiti Kebangsaan Malaysia, Institut Islam Hadhari, Universiti Kebangsaan Malaysia, 43600 Bangi, Selangor, Malaysia

Email: salmy1001@ukm.edu.my

\section{Muhammad Hakimi Mohd Shafiai}

Faculty of Economics and Management, Universiti Kebangsaan Malaysia, Institut Islam Hadhari, Universiti Kebangsaan Malaysia, 43600 Bangi, Selangor, Malaysia

Email: hakimi@ukm.edu.my

\begin{abstract}
This study aims to examine the performance of single mother cooperatives in Peninsular Malaysia. Specifically, the study investigates challenges and factors that contribute to the success of single mothers in cooperative business. Despite many opportunities in operating cooperative business and many among them can achieve commendable success in the cooperative business through training and cooperative skills, the results show that the performance of single mother cooperatives has not been satisfactory and need attention from the government. The study was conducted by evaluating 23 single mother cooperative groups. The analysis of the cooperatives' performance was extracted through detailed interviews with the selected single mothers among the cooperative members. This study found that $61 \%$ of the total number of cooperatives in Peninsular Malaysia were inactive while only $39 \%$ of the cooperatives were still active. The analysis reveals that the higher number of inactive cooperatives was mainly contributed by three main influential factors; which are limited resources, managerial incompetency, and lack of members participation in single mother cooperatives. The results provide additional information and contribution to the involved parties to improve the single mother cooperatives to meet the economic, social, and cultural needs.
\end{abstract}

Keywords: Cooperatives, Single Mother, Performance, Managerial, Peninsular Malaysia

\section{Introduction}

Cooperatives are among the first to give women the right to vote, and they have enabled women to fulfill their potential. When the Rochdale Pioneers Equitable Cooperative Society 
was founded in 1844 women had the right to be full members. Women's issues such as the minimum wage, equal pay, divorce laws, maternity benefits recognized as a priority issue since the Women's Cooperative Guild was set up in the UK in 1883. Today cooperatives continue to contribute to achieving economic, and social empowerment for women, and helping women to find a solution on issues related to equal access to education, health care, decent work, and representation in the political, and economic decision-making process.

In Malaysia, women's participation in cooperatives has increased, and cooperatives continue to become the acknowledged leader in the economy, social, and environmental sustainability model preferred by people. Thus, single mother cooperatives are established to help single mother entrepreneurs to sustain themselves in the economy and survive in a long run. The Malaysia Co-operative Societies Commission (SKM) in cooperation with the Ministry of Women, Family, and Community (KPWKM) has been introducing the single mother cooperative to increase the involvement of single mothers in cooperative entrepreneurship. It is introduced as one of the alternatives to increase the living standards and socioeconomics of the single mother community since they are seen as lagging compared to the whole Malaysian population (Idris \& Ishak, 2003; Abdillah \& Sulehan, 2015).

However, the extent of these impacts is perceived to be limited. The limitations are due to some constraints, which are limited resources, managerial incompetency, and lack of cooperative member participation. In this context, the dilemmas of single mothers are seen as a big issue by the government. Therefore, a continuous effort by government agencies needed to be taken in helping them to start saving, and build their assets (Noor \& Kamil, 2012). To strengthen the single mother economy, and improving the social well-being of single mothers, the Malaysian government has developed Single Mother Empowerment Plan (2015-2020). Specifically, the $4^{\text {th }}$ strategic plan intends to improve the socioeconomic status, and welfare of single mothers through the establishment of cooperatives (KPWKM, 2015). Furthermore, the $11^{\text {th }}$ Malaysia Plan (2016-2020) focuses on providing Malaysians with wellbeing, and prosperity, which is based on the six strategic thrusts, i.e., enhancing inclusiveness towards an equitable society and improving the well-being of all.

Hence, this paper aims to examine the performance of single mother cooperatives in Peninsular Malaysia. The objectives of this study are; firstly to investigate factors that contribute to limited resources i.e cooperative shares and fees. The second objective is to identify the root causes of single mother cooperative managerial competence. The third objective is to assess the factors affecting members participation in single mother cooperatives. This study was conducted through the qualitative method. It involved 23 cooperatives in Peninsular Malaysia from the total number of 28 single mother cooperatives in whole Malaysia, registered with Malaysia Cooperative Societies Commission (SKM). SKM is a regulator and supervisor of cooperatives in Malaysia.

This paper is divided into several sections. The next section is Section Two, which reviews the literature regarding the performance of cooperatives, and the performance of single mother cooperatives in Malaysia. Section Three explains the method used in collecting, and analyzing data while Section Four presents the findings. Lastly, Section Five provides some concluding remarks and relevant recommendations for further study.

\section{Literature Review}

\section{Cooperatives and Performance}

The cooperative means a body people autonomous Emirates voluntarily basis to meet the needs, and aspirations of economic, social, and cultural of the same by an enterprise owned 
jointly, and individually-controlled democracy registered under the cooperative Societies Act 1993 (Malaysia Cooperative Societies Commission). The International Cooperative Alliance (Co-operative Societies Act 1993, Section 2) defined cooperative as an association to meet economic, social, and cultural needs. It refers to "an autonomous association of persons united voluntarily to meet their common economic, social, and cultural needs, and aspirations through a jointly-owned, and democratically-controlled enterprise based on the cooperatives' principles." Cooperative is also a method against capitalism, and it attempts to help lift people from poverty, and destitution. In this context, society is the basis of the economy with the ambition to struggle against the occupation since the beginning of the $20^{\text {th }}$ century (Maulut, Mustafa \& Muhajar, 2015). Cooperatives have always been considered as an economic agency with a strong social responsibility towards the members in particular, and the society at large. Therefore, the performance of cooperatives is portrayed as their success or failure in contributing to society. Cooperatives mostly use financial ratios to evaluate their performance because they are easily understood, and can be calculated using the financial data provided by the financial statements. Besides financial measures such as profitability, the performance of a cooperative can be assessed through liquidity and efficiency. Besides financial performance, the success of cooperatives can be measured by their ability to fulfill other non-financial objectives, including meeting the social needs of the members (Huang et al., 2015). On the other hand, Esa (2015); Kaur (2006) urged that any measurement of cooperative performance must consider the objective and strategic intent of the cooperative organization. It includes ensuring cooperative success in business, maximizing benefits, fulfilling member's needs, and wants.

\section{Financial Performance of Cooperatives}

Despite the financial and non-financial support by the federal government and perceived significant roles played by the cooperatives in Malaysia development, previous studies show that the performance of cooperatives has not been satisfactory especially the Single Mother Cooperatives. Commonly, the single mother cooperatives can develop a rural economy and improve the socio-economic conditions of their members. Because of this, there has been a considerable expectation from these cooperatives to achieve social and economic goals and also spur development and alleviate poverty. However, the majority of single mother cooperatives in Malaysia operate with limited financial resources, and therefore they cannot recruit the best talent, acquire the latest technology, or adopt modern management practices.

A single mother is a group of women who are titled single mothers or widows, are those who continue life without husband and bear children, and are often given negative views by society (Diyana, Padmini \& Idris, 2009). The living standards and socioeconomics of the single mother community are lagging compared to other Malaysian populations (Idris \& Ishak, 2003; Abdillah \& Sulehan, 2015). To survive and compete in the $4^{\text {th }}$ Industrial Revolution (IR4) era, single mother entrepreneurs should not be too dependent on subsidies and the government. Government assistance is an opportunity to strengthen the business, but not a guarantee for the success of entrepreneurs (Ayob, Daud \& Ismail, 2016). The financial situation of a cooperative is in a crucial state mainly caused by the small number of capital contributions from the members. Several cooperatives do not have the share capital although they have been registered for a long time. This situation arises because the members have a low level of awareness about the importance of contribution. Besides, they are not confident in investing in cooperatives. (Nurizah et al., 2016). 
The previous study also revealed that there are lots of supports and channels provided by the government to help single mothers in entrepreneurship. However, there are many of the single mothers who are not successful as an entrepreneur and rely solely on government assistance and supports. Therefore, many single mothers remain in poverty life (Roddin, 2000). Therefore, the continuous efforts by government agencies need to be taken in helping single mothers to start saving and eventually build their assets should take a center stage in poverty alleviation programs. Saving and asset accumulation has been proven to be an important and sustainable means to move the poor out of poverty and improve their economic wellbeing (Noor \& Kamil, 2012).

The role of cooperatives in socio-economic development and poverty alleviation cannot be underestimated based on their principles and values in developing countries. Their importance has been further acknowledged through the United Nations' declaration of 2012 as the International Year of Cooperatives. Cooperatives have significantly contributed to the mobilization and distribution of financial capital by creating employment, income-generating opportunities for members and communities, and helped to reduce inequality and exclusion in society by affording those willing to join opportunities to generate an income (Joseph \& Omona, 2018). Board of Directors 'Finance and planning competency contributed significantly to the cooperative's financial performance. Hence, the board of directors has an important responsibility and role to play in ensuring his or her competency is in line with the need of the cooperatives movement. Only with efficient management will there be a strong cooperative movement that is truly self-help and independent business enterprise. Members who fail to uphold their responsibilities to their cooperatives will destroy the organization (Lajuni et al., 2019). Cooperative membership contributes towards the welfare and betterment of individual members. Subsidiary schemes offered by cooperative proven bring financial and social health to cooperative and members and enable the people to be self-reliant (Rehman, 2020).

\section{Non-Financial Performance of Cooperatives}

In the previous studies, many factors may contribute to the poor performance of cooperatives in non-financial performance. This challenge may be due to a lack of entrepreneurial and managerial skills. Training and education are important elements to enhance the cooperatives' effectiveness. Cooperatives-related agencies and the movement itself must work hand in hand to provide lots of beneficial and more impactful design training programs. This will ensure that a skillful and knowledgeable cooperative community can be established for the future growth of the country (Azmi \& Yacob, 2015). Knowledge sharing capability is important, as lack of employees' sharing capability on the success of knowledge sharing may lead to an inability of the organization to remain competitive (Jalal, Toulson \& Tweed, 2013).

Another issue among single mother cooperatives is the low level of participation by the members in any activities by the cooperatives. They are only interested in participating in activities that directly give economic benefit to their families (Nurizah et al., 2016). Cooperatives are recommended to conduct meeting more regularly and scheduled their annual general meeting. A study reveals that participation by members in any activity of the cooperatives is very low unless the activities give economic benefits directly to the families (Yusop, 2016).

Cooperative has to take appropriate action such as enhancing the capability of the board of directors according to the characteristics of those from excellent cooperatives. If the members of the board have good characteristics such as setting a clear goal, condition- 
oriented personality, knowledge in planning, knowledge in management, as well as high selfmotivated; therefore, the cooperatives have great potential to develop and excellent (Maulut, Mustafa \& Muhajar, 2015). The measurement of cooperative performance must consider the objective and strategic intent of the cooperative organization which can be summarized to ensure the cooperative success in business and maximize benefits and fulfill member's needs and wants (Esa 2015). Improving cooperatives' access to support services is in the strategic plan since nowadays cooperatives required more productive resources to develop them into a stable form of business. More financial capital enables growth in human and social capital. Therefore, cooperatives need to be strengthening the network and linkage of cooperatives with government agencies (Quilloy \& Pabuayon, 2015).

Nevertheless, this study focuses on non-financial performance. Within the implementation of the Malaysian government on specific action plans (2015-2020), there are limited studies on the performance of single mother cooperatives in Peninsular Malaysia on the factors of success or failure. Thus, there is a need to examine the performance, focusing on the challenges and success factors of single mother cooperatives in Peninsular Malaysia.

\section{Qualitative Method}

This study was conducted through the qualitative method. It involved 23 cooperatives from the total number of 28 single mother cooperatives registered with SKM in Peninsular Malaysia. The list of cooperatives was referred to on September 30, 2017. The data were obtained from in-depth interviews with officers from SKM who were assigned to monitor the single mother cooperatives in their district area, single mothers cooperatives, and individual single mothers in Peninsular Malaysia.

This study used two approaches, which were recorded phone conversations and faceto-face conversations. The interview was selected as the data collection approach due to two reasons. First, the study needs data related to the cooperatives' profile, business status, challenges, and poor performance factors that are unavailable to the public. The interviews can gain sufficient information for analysis and provided the value for the preliminary understanding of performance factors that contribute to the success or failure of single mother cooperatives. Second, it is due to the high level of credibility and cost savings. The study is expected to provide an in-depth explanation of why the performance of single mother cooperatives is still not satisfactory.

\section{The Findings: Cases in Peninsular Malaysia}

Based on the interview, the study has detected 14 inactive single mothers' cooperatives from a total of 23 single mothers' cooperatives in Peninsular Malaysia. The Malaysia Co-operative Societies Commission (SKM) would assist these cooperatives by providing them guidance and financial aid to help them resuscitate their businesses. Some cooperatives did not submit full reports on their movements, including in terms of management. Efforts to help these inactive cooperatives are important because some are still in business but have not submitted a report.

From the percentage of active single mother cooperatives, Table 1 shows the recorded name list of cooperatives with an active status. These cooperatives had a higher potential to succeed compared to inactive cooperatives. A series of interviews were conducted through phone conversations with SKM officers in Perak, Selangor, Pahang, Kuala Lumpur, Kedah, Melaka, Kelantan, and Johor. However, the study could not access the complete details of 
some cooperatives, especially on their activities due to private and confidential issues and the rules set by SKM.

TABLE 1. Single mother cooperatives with active status

\begin{tabular}{lll}
\hline No. & Cooperatives' Name & $\begin{array}{l}\text { Establishment } \\
\text { Date }\end{array}$ \\
\hline 1. & Koperasi Ibu Tunggal Lenggong Berhad, Perak & $14^{\text {th }}$ July 2017 \\
2. & $\begin{array}{l}\text { Koperasi Ibu Tunggal Cempaka Biru Daerah Gombak \& Petaling } \\
\text { Berhad, Selangor }\end{array}$ & $29^{\text {th }}$ June 2009 \\
3. & $\begin{array}{l}\text { Koperasi Ibu Tunggal Felda Bukit Kepayang Bera Berhad, Pahang } \\
\text { 4. }\end{array}$ & Koperasi Ibu Tunggal Paya Besar Berhad, Pahang \\
5. & Koperasi Ibu Tunggal Wilayah Persekutuan Kuala Lumpur Berhad, & $18^{\text {th }}$ Jan 2013 \\
& Wilayah Persekutuan & $3^{\text {rd }}$ April 2015 \\
6. & Koperasi Ibu Hati Waja Langkawi Berhad, Kedah & \\
7. & Koperasi Ibu Bestari Melaka Berhad, Melaka & \\
8. & Koperasi Permodalan Kelantan Berhad, Kelantan & $1^{\text {st }}$ April 2016 \\
9. & Koperasi Pertubuhan Ibu Tunggal CARE, Johor & $23^{\text {rd }}$ March 2009 \\
\hline
\end{tabular}

Source: Malaysia Cooperative Societies Commission (SKM)

The total number of inactive single mothers' cooperatives was higher than the active cooperatives. Table 2 shows the list of inactive single mothers cooperatives in Peninsular Malaysia. This preliminary finding indicates that single mother cooperatives were facing many constraints that influenced their poor performance.

Based on the overall interview with active and inactive single mothers' cooperatives, the study found research limitations mainly due to the uncooperative respondent. There are many ways in which the smooth running of an investigation can be negatively affected by the uncooperative respondent. This can arise when; a respondent refuses to answer questions put to them, meaning that the researcher cannot create a coherent picture of the events or the respondent's perspective. Example of responses from the uncooperative respondent is:

We are sorry, we cannot give the information because it was not permitted to share the cooperative information. But the researcher can write to our Director to get the latest information. The researcher can explain what information is needed and for what purposes. Currently, we cannot give information on whether this cooperative active or not active. (Mrs. F from Pahang)

We will reply through email on Koperasi $M M B$ and Koperasi Ibu Tunggal JB. It is difficult to share the information by phone. The researcher has to go direct and meet Malaysia Cooperative Societies Commission (SKM) to get approval. (Mr. S from Pahang). The study found the meeting has been canceled two times and responses are not communicated. The research correspondence was not replied to.

Uncooperative respondents give implication to the sample size too small. Based on this study, a larger sample size could have generated more accurate results. Besides, the introduction as interviewer researcher relies a lot on the information by the respondent. But sometimes they are reluctant to talk. There are a variety of reasons that may cause a respondent to be uncooperative such as; afraid of getting involved, angry for being singled out, defensive, guilty of something, reluctant to inform on work colleagues or friends, agitated 
about having to participate in an investigation and worried about the potential for retaliation (Edkins, 2017). Therefore, it is recommended for single mother cooperative to have competent staff and or management from board members, with proper documents, to communicate with the public and represent the cooperatives in the future.

TABLE 2. Single mother cooperatives with inactive status

\begin{tabular}{llll}
\hline No. & Cooperative Name & Location & $\begin{array}{l}\text { Establishment } \\
\text { date }\end{array}$ \\
\hline 1. & Koperasi Usahawan IITPB & Perak & $26^{\text {th }}$ May 2010 \\
2. & Koperasi Ibu Tunggal CPB & Perak & $26^{\text {th }}$ Nov 2010 \\
3. & Koperasi Ibu Tunggal TKB & Selangor & $9^{\text {th }}$ April 2009 \\
4. & Koperasi RHHLB & Selangor & $5^{\text {th }}$ October 2012 \\
5. & Koperasi MMB & Pahang & $21^{\text {st }}$ Nov 2014 \\
6. & Koperasi Ibu Tunggal JB & Pahang & $31^{\text {st } J u l y ~} 2015$ \\
7. & Koperasi DUITKBB & Kelantan & $15^{\text {th }}$ Dec 2008 \\
8. & Koperasi Ibu Tunggal Dan Wanita PSB & Kedah & $4^{\text {th } ~ J u l y ~} 2014$ \\
9. & Koperasi Ibu Tunggal INMB & Melaka & $1^{\text {st }}$ April 2013 \\
10. & Koperasi Ibu Tunggal JBN9 & Negeri Sembilan & $17^{\text {th }}$ Feb 2009 \\
11. & Koperasi Ibu Tunggal BBPPB & Pulau Pinang & $26^{\text {th }}$ Aug 2010 \\
12. & Koperasi Ibu Tunggal PPB & Pulau Pinang & $6^{\text {th }}$ April 2009 \\
13. & Koperasi Ibu Tunggal MMBB & Pulau Pinang & $29^{\text {th }}$ Jan 2010 \\
14. & Koperasi Ibu Tunggal ABPB & Perlis & $29^{\text {th }}$ Apr 2010 \\
\hline
\end{tabular}

Notes: The inactive cooperatives name was put under private and confidential.

Source: Malaysia Cooperative Societies Commission (SKM)

To obtain additional information on inactive cooperatives, the study has interviewed the SKM officers who have volunteered to be an informant and represented by active and non-active single mother cooperatives. From the results of the successful interviews, the analysis of findings reveals that there were significant factors that contributed to the poor performance of single mother cooperatives.

TABLE 3. Recorded interviews among the SKM officers

\begin{tabular}{|c|c|c|c|c|}
\hline No. & Respondent & Location & Position & Interview Date \\
\hline 1. & Informant 1 & Perak & SKM Officer & $18^{\text {th }}$ July 2018 \\
\hline 2. & Informant 2 & Selangor (I) & SKM Officer & $26^{\text {th }}$ July 2018 \\
\hline 3. & Informant 3 & Pahang & Single Mother & $25^{\text {th }}$ July 2018 \\
\hline 4. & Informant 4 & Pahang & SKM Officer & $26^{\text {th }}$ July 2018 \\
\hline 5. & Informant 5 & Kedah & SKM Officer & $25^{\text {th }}$ July 2018 \\
\hline & Informant 6 & Kedah (II) & SKM Officer & $25^{\text {th }}$ July 2018 \\
\hline 6. & Informant 7 & Melaka & SKM Officer & $26^{\text {th }}$ July 2018 \\
\hline 7. & Informant 8 & Perak II & SKM Officer & $19^{\text {th }}$ July 2018 \\
\hline 8. & Informant 9 & Kelantan & Single mother & $25^{\text {th }}$ July 2018 \\
\hline 9. & Informant 10 & Perlis & Single Mother & $19^{\text {th }}$ July 2018 \\
\hline 10. & Informant 11 & Johor & Single mother & $20^{\text {th }}$ July 2018 \\
\hline 11. & Informant 12 & Selangor (II) & SKM Officer & $20^{\text {th }}$ July 2018 \\
\hline
\end{tabular}


The analysis of findings reveals that many factors contributed to the poor performance of single mother cooperatives instead of their success. The percentage of non-active cooperatives was higher than the active cooperatives; hence, this study focuses on factors that contribute to the failure and poor performance of non-active cooperatives. The analysis indicates that three main factors were perceived as important in influencing the poor performance of single mother cooperatives in Peninsular Malaysia. The three factors include limited resources, managerial incompetence, and members participation are summarized in Table 3 as per below:

Table 3. Factors Of Poor Performance Of Non-Active Single Mother Cooperatives

\begin{tabular}{|c|c|c|}
\hline No. & $\begin{array}{c}\text { Factors of Poor } \\
\text { Performance }\end{array}$ & Causes and Effects \\
\hline 1. & Limited resources & $\begin{array}{l}\text { - limited resources to operate the organizations } \\
\text { - majority of cooperatives members paid a minimum entry } \\
\text { - } \text { fees and shares } \\
\text { - difficult to organize programs due to the limited amount } \\
\text { - of shares capital } \\
\text { - dependence on subsidies and sponsors }\end{array}$ \\
\hline 2. & $\begin{array}{l}\text { Managerial } \\
\text { incompetence }\end{array}$ & $\begin{array}{l}\text { - } \text { run program without approval from the board of } \\
\text { - } \text { members } \\
\text { - } \text { nonds and expenses are not recorded } \\
\text { - the in-charge person is found not active and cannot be } \\
\text { contacted } \\
\text { - lack of competent staff and management problem } \\
\text { - replacement of the chairperson }\end{array}$ \\
\hline 3. & $\begin{array}{l}\text { Members } \\
\text { participation }\end{array}$ & $\begin{array}{l}\text { - } \text { no cooperative member since registered } \\
\text { - } \text { busy with a background of political activities } \\
\text { - } \text { difficult to gain members trust } \\
\text { - } \text { single mothers have their product and market them in } \\
\text { - } \text { individualistic and lack of co-operation among members } \\
\text { - } \text { disagrees to make a small contribution to the cooperative } \\
\text { - not cooperating and difficult to commit } \\
\text { - } \text { not willing to listen to good advice }\end{array}$ \\
\hline
\end{tabular}
Source: Researcher's analysis

\section{Limited Resources}

First, the factor is limited resources. Most of the non-active single mother cooperatives have limited resources to operate organizations. The majority of cooperative members paid minimum entry fees and shares. Consequently, the limited amount of share capital causes difficulties for cooperatives to organize programs. Programs such as survival programs are important to ensure the cooperatives keep active after one year of establishment. Otherwise, the cooperatives are categorized as inactive. The informants narrated: 
"Majority Koperasi Ibu HWLB members paid minimum entry fees and shares. There are 20 members only paid for minimum shares. Therefore, those who do not pay entrance fees or minimum shares will not be considered cooperative members and not entitle to any profit. They are also not eligible to come for Annual General Meeting. At the same time, we have advised the cooperative to reduce the required membership fees RM300 to less than that amount because single mothers are not effort to pay the amount. When the membership fee is high, people are not interested to join the cooperative. In the current situation, the cooperative has a limited amount of shares capital causing difficulties to do programs. Finally, we were told that the cooperative has run a program without approval from the board of members. At the same time, funds and expenses were not recorded and this will result in difficulties in preparing documents for audit purposes."

(Informant 5).

"Koperasi Ibu Tunggal Dan Wanita PSB has no cooperative member since registered and not collected any share. Their background is political activities and they are very busy. They have submitted to SKM a proposal on a small scale and middle scale industry product, catering, and laundry. Their projects are also from UMNO's programs. Cooperative needs a new program but unfortunately, they are on their activities. On registration, they have 50 potential members on the list, but they are not collecting any fees. It is difficult to gain members' trust to pay shares when the cooperative has no activities. Besides, if they're only one-man shows, the cooperative can't survive. Finally, she will feel "down". Sometimes, we must think, in the beginning, they are eager to establish a cooperative because at that time they may have the intention to seek government assistance. But when they cannot get assistance, everybody keeps silent. Those single mothers use to have their product, so running a cooperative is difficult. If the cooperative chooses the main activity of a grocery store, it is difficult to operate because they have a high commitment to their business. Normally, we give 3 years minimum for a cooperative to cancel the registration. We have sent a letter and ask them to come and discuss to cancel, they refused. So, the cooperative remain "hanging". Then they reply they will come in a month. SKM followed but finally, nothing improves. The in-charge person as per SKM record system was found not active and cannot be contacted."

(Informant 6)

It is undeniable that cooperatives cannot run programs or business activities due to budget constraints. However, too much dependency on government assistance is not a guarantee for success compared to attitudes and values. This factor is mentioned by Ayob et al (2016) as the most influential factor for the survival and success of cooperatives.

Another factor that is part of limited resources is the dependence on subsidies and sponsors. Although various facilities and assistance are given in the form of financial and facilities equipment, many single mother co-operators failed in their business because they are too dependent on government agencies. Most of the active and inactive cooperatives depend on subsidies and sponsors by the government to operate their organizations and run their business activities. Instead, co-operators who are successful and competitive is not dependent on the government. The informants narrated:

"Although various facilities and assistance were given in the form of financial and facilities equipment single mother co-operator and who failed in business areas remain high because the attitude is too dependent on government agencies. Co-operators who are successful and 
competitive do not dependent on the government. Government assistance is not a guarantee against someone's success attitudes and values."

(Informant 8)

"The cooperatives active but currently there is no activity due to budget constraints. The previous program was sponsored by the parliament office (local government) for 900 single mothers. The cooperative was established with the share capital contributed by the local government. Every single mother received a total of RM50.00 in form of cooperatives share capital. Balance of RM50.00 was paid by single mother own. The total share is RM100.00. The purpose of opening the cooperative is to sell single mothers' products. He has advised the cooperative to actively promoting membership since the money has been received from the local government. The cooperative expenses and income are very low. Therefore, they estimate the audit session will be done quickly. I have confirmed that the 900 single mothers were calculated based on parliament data. However, total cooperatives members are 60 people."

(Informant 8)

"The cooperative is no more in operation because the chairperson has died. SKM was not informed about this. When we first plan to open the cooperative, there are many single mothers together in the project but due to budget constraints and cannot get the donation, we have to stop the operation."

(Informant 9)

"The cooperative-related agencies are foreseen that if the assistance was provided to the particular single mother in the form of financial, it will encourage the member to be overly dependent on local government."

(Informant 1)

\section{Managerial Incompetency}

In accessing the impact of managerial incompetence on the growth of single mothers' cooperatives the study will be looked to what extent does managerial competence affects the growth of a small business. The informants narrated:

"The paperwork on the single mothers' cooperative project was initiated in 2010. There are 25 to 30 people in the cooperative. Most of the members are single mothers who business from home; making traditional snacks (kerepek), handicrafts, homemade chocolate, traditional cakes and, biscuit. The project is under Women Development Department. The department director was the one who suggests to the single mothers' group to establish a cooperative. There are 20 single mothers sent to KEMAS to take the Level 1 Skill Certificate. The cooperatives also go out and market the product at Seberang Jaya. The cooperative is very active at Lubuk Sireh, especially on the open day. They have many projects but after the chairperson resigned and the new chairperson take over 2 years, they are not sure what happened next. The new management gets a new project fully supported by a government grant. But the project was not a success and finally the cooperative discontinued after 3 years."

(Informant 10) 
Lacking a capable board of directors according to the characteristics of those from excellent cooperatives. Most of the board doesn't have good characteristics such as setting a clear goal, condition-oriented personality, knowledge in planning, leadership, management as well as a high level of motivation. Besides, the cooperative boards do not convince meeting regularly as that dictated by the cooperative rule. They are also lack of motivation to sustain themselves in business.

"Single mother needs attention and guidance. This single mother cooperative is initially from a single mother association. The association collaborate their program with the head of departments (political party) and finally established a cooperative. They believe that cooperative is a platform for them to get the source of income. The association is for members' welfare and social matters."

(Informant 2)

From the perspective of the management of cooperatives, the board members are below 50 years of age, with most of the chairmen, secretaries, and treasurers having little experience of cooperative board members. Management takes over was not done and communicate effectively.

"Some cooperatives are led by incompetent board members. The majority of single mother cooperatives have a small amount of capital and are managed voluntarily by board members who lacked managerial skills. As a result, the majority of single mother cooperatives are not skillful in handling the financial resources of their business and they are dependent on opportunity and assistance from the government."

(Informant 1)

"A specific single mothers cooperative survival program needs to be carried out for single mothers cooperatives that have been dormant and almost non-operational. The program is recommended to single mothers cooperative which not active after one year of establishment. It is also open to anyone interested to enable them to develop themselves and seized opportunities in the cooperative market. In this respect, courses in areas such as business administration, management, marketing, product development, quality control, and business expansion will be conducted from time to time either by cooperative agencies."

(Informant 1)

Lacking knowledge about cooperative business and opportunities as well as various assistance schemes provided by various government agencies other than cooperative agencies. Besides, some single mothers are not skilled to handle the financial resource of their business. Then, training was attended by managers but not their members. Therefore, members' knowledge doesn't improve. Single mothers lack business knowledge such as sales techniques, service and product marketing; and business expansion. They have improper business planning and a lack of management skills.

"SKM has advised the members of the board to change the way of management because managing association cannot be the same as managing cooperatives due to rules as set in Cooperative Act. They have to comply with the act." 
"Lacking training and exposure on aspects related to entrepreneurship and cooperative business such as cooperative marketing, product development, quality control, business administration, financial management, and business expansion."

(Informant 7)

Cooperative could not continue after the death of their founder;

"Cooperative still active. We only rent the office at Pejabat JKKK Lama, Tapak Pekan Sehari. But, we are running the coop without a chairperson because she has resigned."

(Informant 3)

"The cooperative is no more in operation because the chairperson has died. SKM was not informed about this. When we first plan to open the cooperative, there are many single mothers together in the project but due to budget constraints and we cannot get the donation, we have to stop the operation."

(Informant 9, Single Mother's Cooperative Member)

'The Cooperative still active but the business low turnover. Another cooperative named Koperasi ITINMB was dormant and will be canceled soon. The cooperative chairperson mates an accident and has given the authority to new management."

(Informant 6)

\section{Member Participations}

"Single mothers are too individualistic. Single mothers have been given skills training, but they are doing their own business. Cooperative is active but the activities were done individually and no cooperation with each other. The product was marketed in small quantities through the WhatsApp group. They are not able to meet the demand. Single mothers are difficult to commit to any project because they have their problems. They have received skills, capital, advice, and grant thru cooperative. But, when they succeeded, they said they wanted to be independent or leave the cooperative. The reason is that they disagree with the profit to be shared with the cooperative. In the beginning, the cooperative had 50 members, so we could ask for a grant. But suddenly when we invited them to the annual general meeting, some incite members to leave the cooperative. Each of them disagrees to make a small contribution to the cooperative, they are not cooperating, difficult to commit, and not willing to listen to good advice."

(Informant 11)

"Koperasi Ibu Tunggal TKB has no longer in operation. It was established to help single mothers marketing their homemade products. The cooperative still not cancel. SKM has assisted them to get RM30,000 for the beauty spa business. The SPA was a success in the beginning, but due to a lack of competent staff and management problems, the cooperative has not continued the business. However, their experienced staff still attending to mobile beauty spa service calls. Besides the beauty spa business, they also produce crispy ground nuts. The cooperative members are women and single mothers come from a poor family. They can't effort to buy enough food and others. Their husband in jail or a detention center. Some are still young, with children but have no husband. I have initiated the program with another cooperative (cooperative for Petronas officer wife) to produce a recipe book title Taste of 
Jeram at RM99 per book. Those single mothers or anyone who has contributed the recipe will get a royalty. Therefore, a single mother will have money for her survival."

(Informant 12)

"In the beginning, the cooperative has no guidance to run cooperatives. Most of the members are busy with other activities. The chairman said that she could not handle the cooperative with only a few members of the board."

(Informant 2)

Cooperatives have always been considered as an economic agency with a strong social responsibility towards the members in particular and the society at large. Many factors contribute to the success of cooperatives such as members participation depending on the age and education of the members, their level of investments, the usefulness of the cooperative to members, and their technical skill. Informant 2 mentioned the factors that contributed to the success of Koperasi Ibu Tunggal Cempaka Biru Daerah Gombak \& Petaling Berhad, Selangor (Group 2 -Rawang):

"The ability of cooperative to run well, overcome the various challenges and be successful depends a lot on many internal and external factors. Among the factors that have been identified to be associated with the success of the single mother cooperatives are the capacity of the single mother community, support, and cooperation from external entities, commitment and leadership, and relationship with the single mother community. Single mother needs attention and guidance. This single mother cooperative is initially from a single mother association. The association collaborate their program with the head of departments (political party) and finally established a cooperative. They believe that cooperative is a platform for them to get the source of income. The association is for members' welfare and social matters."

When asking about the financial facilities offered by SKM to single mother cooperative, informant 2 said;

"SKM Gombak-Hulu Langat was the biggest region with the largest number of cooperative (450 cooperatives) in Selangor. To get financial assistance from SKM, the minimum duration of the cooperative operation is 18 months. Koperasi Ibu Tunggal CB (Group 2-Rawang) has shown their good performance within the period and therefore SKM has invited them to join National cooperative Day and other related programs to enhance their skill and knowledge. In the beginning, there are only 49 members. The cooperative has succeeded in its application to get RM50,000.00 funds from SKM. They have opened their bakery and received many orders from the communities. The cooperative has form groups consist of 4 members, with a different task, for example, a group for traditional foods, a group for cakes and biscuits; and they will promote and sell the product. Net profit will be shared among members. The researcher is welcome to visit the bakery."

(Informant 2)

\section{Recommendation and Conclusion}

Hence, this study aimed to examine challenges contributing to the survival of single mothers in the cooperative. Aspects, which are the focus of the study is that factors that contribute to 
the success of single mother in the field of the cooperative. In that scenario, their single mother cooperative development plans are recommended as the potential role of SKM so that the burden of cultivation on the single mother can be minimized.

The findings imply the need for single mother cooperatives to be managed professionally for efficiency and increasing the ability to provide social amenities for their members due to the lack of funds. Most single mother cooperatives do not have any stable income-generating activities, and it is difficult to fulfill the social obligations towards the members causing the cooperative members to leave the organization or become not active. Therefore, there is a need for a training program for members of boards and those about to venture into cooperatives so that the risk of business failure is minimized and they would not be saddled with ineffectiveness. The agencies responsible for cooperatives and the development of single mothers should provide exposure, supervision, and monitor the cooperatives programs closely.

However, before embarking on the development of a single mother cooperative training program for the boards and members, one needs to conduct a Training Needs Analysis (TNA). This is to determine the venue, what to teach, and who should attend such training Cooperatives College of Malaysia is one of the institutions that play an important role to help transform cooperatives to be more creative, innovative, and competitive. TNA examines the returns on training investment and it is the initial step in the cycle of training. It helps one to minimize the risk of making mistakes in training programs and development and ensure the effectiveness of the training programs concerned (Azlifah, 2016).

Effective leaders must have proper business planning and management skills. The board members of cooperatives must have the appropriate knowledge and experience in formulating policies and decision-making while managerial employees should have relevant knowledge and experience to implement the policies and daily operations of the cooperatives. Besides, business knowledge such as sales techniques, service and product marketing; and business expansion will also contribute to business success.

Education and skill training on business planning, business management, marketing, internal control, financial management, and other specific areas should be made available for the single mother community, entrepreneurs with potential, and cooperatives members. The training must be conducted at their location to encourage high participation and attendance. Skill development programs should focus on business areas identified to have the potential to grow in the locality. Their activity will be monitored and successful cooperatives will be guided to a special program on the preparation of working papers and provide the cooperatives project grant. Special recognition for success single mother cooperative will inspire and create interest in single mother towards cooperatives.

The responsibilities of improving the economy of a single mother and their cooperatives should not place on their shoulder, but should also be shouldered by the community, government agencies, private sectors, NGOs, and government-linked companies (GLC). The involvement of the private sector can be in form of becoming investors, shareholders, and business partners in their traditional business as well as in new knowledgebased business ventures. The single mother cooperative should actively initiate activity with collaboration with agencies from the government, NGOs, and GLC. Besides saving the cost of handling programs, cooperatives will expose more opportunities in the future. Grant of incentive business venture as an encouragement to the next higher level for growth and business expansion since the beginning of cooperative operations to encourage focus cooperative group members. At this level, the mentoring system is recommended. The 
decision to embark on any industry should be based on the local demand, and availability of resources and skills. A single mother must be provided with business training with access to funding, assistance in getting material supplies, and marketing the products. In addition, the mentoring program should be designed to ensure that entrepreneurs and cooperatives are successful.

At the same time, there is also a need to strengthen the network and linkage of single mothers cooperative with government agencies, private sectors, and NGOs. The various agencies, communities, and investors must formulate strategies through cooperation and partnership to encourage entrepreneurship activities and establish a single mother business platform within the communities, emphasizing small group participation and through cooperatives. Among the cooperative platform, the product that is feasible for single mother is food-based products such as cakes and biscuits, catering, canned and bottled food such as cooking paste or ready-made food mixture; handicraft and consumer goods such as clothes.

In conclusion, besides the support services, strong organizational structure, entrepreneurial and managerial skill, the most important factors in ensuring the success of a business are knowledge and the basic combination of entrepreneurship such as the characteristics of the private, patience, vision and not easily give up. The combination of this quality is important because it will make the entrepreneur always strive to profit from his business. This step enables them to get around capital business and gain as much experience and the skills required in the conduct of a business. The entrepreneur should have the characteristics of entrepreneurship and smart enough to dominate the business. In other words, success factors and the ability of entrepreneurs depend on the level of knowledge that it owns. Single mothers have to prepare mentally and physically for business.

\section{References}

Abas, A., Kassim, N. A., Ali, N. A., Hanif, F. M., \& Safian, J. S. (2016). Training needs analysis for Malaysia credit co-operatives. Malaysian Journal of Co-operative Studies, 12 (2016), 5364, ISSN: 2600-7290.

Abdillah, K. K., \& Sulehan, J. (2015). Kemunduran sosioekonomi dan penyisihan sosial komuniti bumiputera di Bandaraya Kuching: Kajian kes di Kampung Kudei Baru dan Kampung Sinar Budi Baru Batu Kawa. GEOGRAFIA Online Malaysian Journal of Society and Space, 11(13), 131-141.

Ayob, N. A., Daud, S., \& Ismail, M. T. (2016). Modal insan, daya saing dan prestasi usahawan wanita di Malaysia: Analisis kualitatif usahawan wanita bumiputera di Melaka. GEOGRAFIA Online Malaysian Journal of Society and Space, 12(10), 56-67.

Azmi, A.A., \& Yacob, Y. (2015). The effectiveness of training programs among co-operative members in Sarawak. Malaysian Journal of Co-operative Studies, 11 (2015), 45-58, ISSN: 2600-7290.

Edkins, G. (2017). Witness Interviewing: How to dealt with reluctant witnesses. https://www.safetywise.com/single-post/2017/04/18

Esa, A. M. (2015). Measuring economic and social efficiencies of area farmers organisation in Malaysia. Malaysian Journal of Co-operative Studies, vol. 11 (2015), 93-106 ISSN: 26007290.

Idris, N., \& Ishak, Y. (2003). Sektor Tidak Formal dan Kemiskinan Bandar. In Idris H. I., \& Chamhuri, S (eds). Kemiskinan bandar dan sektor tidak formal di Malaysia, pp. 23-40. Penerbit UKM, Bangi. 
Isahak, D., Padmini, D., Selvaratnam and Idris, N. (2009). Isu Dan Cabaran Ibu Tunggal Dalam Menghadapi Perubahan Persekitaran Global. Prosiding Persidangan Kebangsaan Ekonomi Malaysia (PERKEM IV) Jilid 1 (2009) 324-336 ISSN: 2231-962X

Jalal, H. A., Toulson, P., \& Tweed, D. (2013). Knowledge sharing success for sustaining organizational competitive advantage. Procedia Economics and Finance 7, 150-157.

Joseph, A., \& Omona, J. (2018). Survival Strategies of Producer Cooperatives in Uganda: A case study of Nyakatonzi Growers' Cooperative Union, Kasese Distic. Malaysian Journal of Cooperative Studies, vol. 14 (2018), 63-85, ISSN: 2600-7290.

Kaur, I. (2006). Performance measurement. An evaluation of cooperatives performance in Malaysia. Malaysian Journal of Cooperatives Management, vol.2 (2006),1-17, ISSN: 26007290.

KPWKM. (2015). Pelan Tindakan Pemerkasaan Ibu Tunggal (2015-2020). Langkah Strategik 4: Meningkatkan taraf sosioekonomi dan kebajikan ibu tunggal melalui pewujudan koperasi. Retrieved on March 17, 2020 from https://www.kpwkm.gov.my/kpwkm/uploads/files/ Dokumen/BUKU\%20PELAN\%20TINDAKAN\%20PEMERKASAAN\%20IBU\%20TUNGGAL.pdf Lajuni, N., Ali, M. P., Yacob, Y., \& Tarip, Y. (2019). Board of Directors'Finance and Planning Competency Influence on Co-operative's Financial and Non-Financial Performances. Malaysian Journal of Co-operative Studies, vol.15 (2019), 1-10, ISSN 2600-7290.

Maulut, M. K., Mustafa, N., \& Muhajar, A. J. (2015). The resilience concept of Islamic entrepreneurs and the promoting of Islamic financing products to credit co-operatives in Malaysia. Malaysian Journal of Co-operative Studies, 11(2015), 25-41, ISSN: 2600-7290.

Noor, Z. M., \& Kamil, A. (2012). Sustaining of Livelihood of Single Mothers Through Wealth Creation dan Saving Opportunities: A Long Road Ahead. International Journal of Trade, Economics and Finance, Vo. 3, No. 2, April 2012, 126-130.

Noordin, N., Said, S. A., Hassan, S. K., Yusop, J., \& Golam, A. A. (2016). Development and prospect of Orang Asli Co-operatives: A case study of Perak and Pahang. Malaysian Journal of Co-operative Studies, vol.12, 1-17, ISSN:1823-5387.

Quilloy, K. P., \& Pabuayon, M. I. (2015). The Philippine co-operatives enterprises towards sustainable development: A perception study. Malaysian Journal of Co-operative Studies, 11 (2015), 1-21, SSN: 2600-7290.

Rehman, M. (2020). Cooperatives' Membership and Well-being of Farmers: An Empirical Evidence, Based on Interest-Free Tractor Scheme for Barani Areas From District Narowal., Pakistan. Malaysian Journal of Co-operative Studies, vol. 16 (2020), 89-107, ISSN: 26007290.

Roddin, R., Sidi, S. S., Yusof, Y., Mohamed, M., Razzaq, A. R. (2000). Poverty Alleviation Among Single Mother in Malaysia: Building Entrepreneurship Capacity. International Journal of Business and Social Science, vol.2 no.17, 92-98. www.ijbssnet.com.

Study of Perak and Pahang. Malaysian Journal of Co-operative Studies. Volume 12 (2016)

ISSN:1823-5387. Pg.1-17. Petaling Jaya: Co-operative College of Malaysia (CCM)

Yusop, J. M. (2016). Development and Prospect of Orang Asli Co-operatives: A Case 